\title{
Improving the Properties of Amylolytic Enzymes by Protein Engineering
}

\section{タンパク質工学をもちいた澱粉分解酵素の性質改良}

\author{
Crabb, Douglas W ; and Shetty, Jay \\ Genencor International, Inc., California Technology Center, 925 Page Mill Rd., Palo Alto, CA 94304 \\ FAX:1-650-621-7823, E-mail: Dcrabb@Genencor.com
}

Key Words : protein engineering, amylase, glucoamylase, starch, processing

\begin{abstract}
Modifying the properties of enzymes and proteins has become a relatively routine practice in both the academic and the bioindustrial sectors since the first introduction of the concept in the late 70's to early 80 s. The original tools of sitespecific modification and three dimensional structural analysis based design have expanded to include regio-targeted mutagenesis, homology based recruitment of amino acid residues and in vivo and in vitro recombination of genes. The advent of PCR based methodologies for gene cloning and manipulation have greatly increased the ability to design altered proteins yet at the same time have made the process less time-consuming as well. Add to this the ability to introduce thousands, if not millions, of variations into existing proteins, the rapid development of robotic based handling and screening systems and one has the basis for a revolutionary excursion into protein design. Yet in spite of all this capability, the successful outcome of a commercial protein engineering project remains based in three quite simple fundamental principles. First, one must have a clear understanding of the real world application conditions under which an enzyme is used and how these conditions can define what actually constitutes an improvement in the performance of the enzyme. Second, one must be able to quantitate what the improved property can deliver in terms of process value to the customer. And third, but clearly not the least, one must understand the key commercial features which can expedite or hinder the actual commercialization of a new product. These three questions can be restated in non-scientific terms as: what does the customer need?; what value will this bring to the customer?; and how can the product be delivered to the customer so that value is recognized by all? These three questions will form the basis of the following discussion on engineering improved amylolytic enzymes to the starch industry.
\end{abstract}

要 約

酵素やタンパク質の性質変換は、最初にこの技術が紹介さ れた 1970 年代後半から 1980 年代前半以来、学問的および産業 的分野の双方で比較的日常的に行われるようになってきてい る。部位特異的変異や三次元構造分析を基盤にした分子設計の 元々の手法は、目的部位への変異の導入、相同性を基盤にした アミノ酸残基の探索、および in vivo や in vitro での遺伝子の組 換えにまで広がりをみせている。遺伝子クローニングや操作の ための PCR 法の出現は、変異タンパクを設計する能力を飛躍的 に向上させたが、更にその工程での時間の浪費を少なくした。 既存のタンパク質に、何百万ではないにしろ、何千という変異 を導入する能力、ロボットによる操作やスクリーニング・シス テムの急速な発展に加えて、我々はタンパク質の設計に革命的 な変異の基礎を手に入れた。全てのこの能力にもかかわらず、 いまだ商業的なタンパク質工学のプロジェクトの成果は三つの 全く簡単な基本的原則に基礎をおいている。まず第 1 に、我々 は酵素が使われる現実の応用条件と、これらの条件が酵素作用 の改良で実際の構成要素となるものを如何に規定するかについ て明確に理解しなければならない。第 2 に我々は改良された 性質が製造工程の価値として何を顧客にもたらすかを定量でき なければならない。そして第 3 にしかし明らかにこれのみで はないが、新製品の実際の商業化を促進する又は阻害する重要 な商業化の要素を理解しなければならない。これら三つの質問 は、顧客のニーズは？どのような価値を顧客にもたらすか？ そして、価值が皆に理解できるように如何に顧客にその製品を 納入できるか？という非科学的用語として述べることができ る。これら三つの質問は、改良された澱粉分解䤃素を澱粉工業 会向けに応用する際に以下のような議論の基礎をなしている。

A. はじめに

酵素は商業的に利用された長い歴史があり、幅広い分野に わたって生産物が作られている。醸造用のための大麦の糖化や 
such as the malting of barley for brewing, or calf stomach extracts for cheese production, predate the discovery of enzymes. Yet it is in the starch processing industry that enzymes have truly defined both the process conditions and the quality of the product. In fact, of all the major commercial applications in wide spread use today, the starch processing industry is the single one that is based primarily on enzymatic processes.

Starch represents one of the most widely available biobased feed stocks in the world. With no exceptions, starch based crops are grown in all developed parts of the world. Whether it is maize in the US, wheat in Europe or cassava in the Asia Pacific regions, starch is widely available as a starting raw material. As a raw material the starch from such crops can be extracted as insoluble anhydrous starch granules, can be partially hydrolyzed to shorter chain soluble maltodextrins, or can be hydrolyzed to maltose or glucose. The maltose and glucose can be used as is or can be further treated enzymatically to yield iso-malto-oligosaccharides or high fructose corn syrup (HFCS) respectively. In order to simplify the discussion, we will focus on the starch to HFCS process as one representative of the industry and suggest that the same criteria and technology applied here could be applied to other amylolytic processes as well.

\section{B. The Enzymatic Processing of Starch}

Acid hydrolysis had become the predominant conversion process for starch in the early twentieth century. Acid conversion is non-specific, resulting in random hydrolysis of internal glycosidic linkages, and the manufacturer lacks ways of controlling saccharide composition and the degree of conversion. Acid hydrolyzed starch with a dextrose equivalent (DE) below 30 tends to cloud upon storage as a result of retrogradation of the longer chain linear polymers (amylopectin). On the other hand, a starch hydrolysate with a DE greater than 55 promotes the formation of excessive amounts of glucose degradation products such as 5- hydroxy methyl furfural, that are difficult to remove during refining. The undesirable by-products due to the chemical degradation of glucose under severe processing conditions (low $\mathrm{pH}$ and high temperature) also result in lower product yield. The lack of process control, yield loss, high refining costs and process safety concerns led the development of the enzymatic process replacing acid hydrolysis for starch. By the 1960s enzymatic processing became the standard of the industry. Figure 1 outlines the processing steps, the conditions and the enzymes most widely in the industry today. Of note is that there are a series of temperature and $\mathrm{pH}$ changes throughout the process. These changes do not reflect the optimal desired process conditions; instead, they reflect the operating conditions under which the enzymes can perform. Several review articles on the dynamics of the overall process and enzymes involved can be a source of more detail $(1,2)$.
チーズ製造のための子牛の胃の抽出物のような䤉素の応用は、 酵素の発見より以前に行われていた。それでも、酵素は生産物 の加工条件と品質の双方を規定するということは澱粉加工工業 において明示することが出来る。事実、今日広範囲に広まって いる主要な産業的応用の中で澱粉加工業は、醳素加工を基礎と する唯一のものである。

澱粉はこの世で最も広く入手可能な生物基盤の食料資源で ある。例外なく、澱粉基盤の作物は世界の多くの開発地域で栽 培されている。アメリカにおけるとうもろこし、ヨーロッパの 小麦、アジア・オセアニアのキャッサバにせよ、澱粉は出発原 料として広く入手可能である。原料としてこのような作物から の澱粉は不溶性の澱粉粒として抽出されるか、部分加水分解さ れ短鎖の水溶性マルトデキストリンになるか、加水分解されマ ルトースやグルコースになる。そのマルトース、グルコースは そのままで用いられるか、さらにそれぞれ酵素処理されイソマ ルトオリゴ糖や異性化糖 (HFCS) に変換される。話を単純化す るために、産業の代表例として異性化糖製造に焦点を合わせて 以下に記述する。ここで応用された基準や技術は他の澱粉分解 工程にも同じょうに応用できる。

\section{B. 澱粉の酵素分解}

20 世紀初めには、酸加水分解が澱粉の主要な変換手段に なっていた。酸加水分解は、澱粉のグルコシド結合をランダム に分解するという特異性のないものであり、糖組成や分解率を コントロールするのは困難である。DE (Dextrose equivalent) 30 以下の酸加水分解物は保存中に長い直鎖分子 (アミロペクチン) が老化し濁ってくる傾向がある。一方 DE55 以上の加水分解物 は 5-ヒドロキシメチルフルフラールのような過度のグルコース 分解物の生成を促進し、精製工程でも除去が困難である。過酷 な加工条件 (低い $\mathrm{pH}$ 、高温) 下でグルコースが化学分解される ことによるこの望ましくない副生成物は、結果として収率を低 下させる。工程管理の欠如、収率ロス、高い精製コストや安全 な工程への関心は、澱粉の酸加水分解に代わって䤉素分解への 開発へと導いた。1960 年代までに酵素法は産業界の標準になっ た。図 1 に、現在広く使用されている工程、反応条件、酵素の 概略を示している。各工程を通して温度と $\mathrm{pH}$ に変化がある点 は注意すべきである。これらの変化は最も好ましい工程の条件 を反映していない。ただ酵素が作用し得る操作条件を反映して いる。全般的な工程の動力学、使用する酵素についてより詳細 に記述されている解説記事がいくつかある。(1、2) 


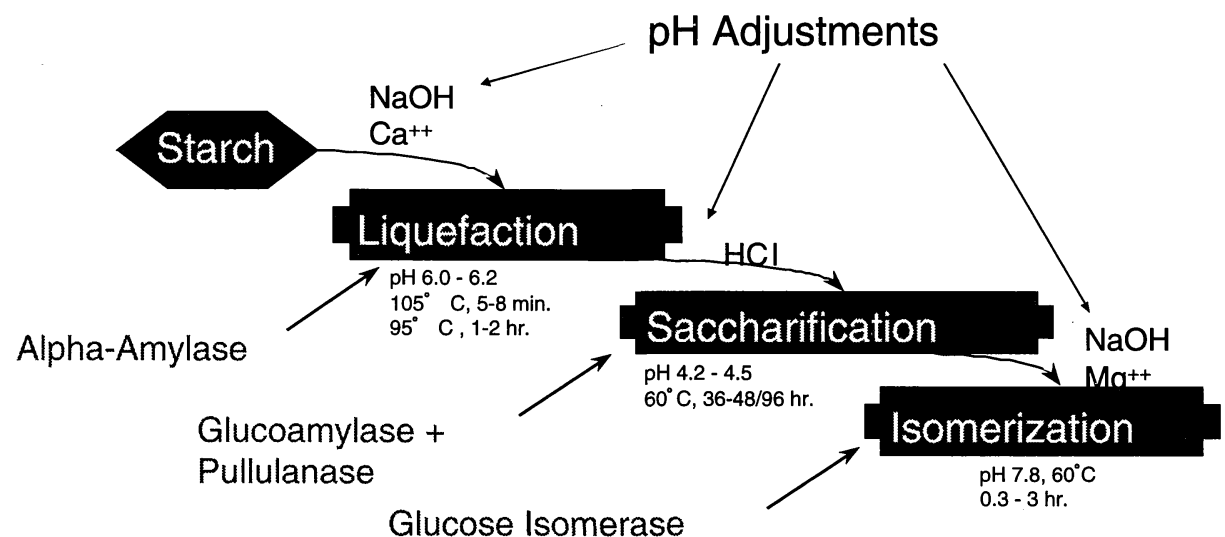

Fig. 1. Commercial Process for Starch Processing. Indications of operating conditions such as $\mathrm{pH}$ and temperature adjustments are those standard in the industry but may vary depending upon the starch source, the products manufactured or individual plant operations.

\section{Enzymatic Liquefaction}

Thermostable alpha amylases are the first of the enzymes applied to starch processing. As indicated in Figure 1, traditional process parameters are at $\mathrm{pH}>6.2$ and in the presence of calcium. These conditions were essentially defined by the minimum operating parameters of the amylases available at the time. The enzymes used for the large-scale hydrolysis of starch and their sites of action are outlined in Figure 2. Bacillus licheniformis $\alpha$-amylase (BLA; EC 3.2.1.1), which is the enzyme of choice in the industry, requires calcium for performance at high temperatures. In addition, as the $\mathrm{pH}$ is lowered, enzyme performance is negatively affected and to operate below $\mathrm{pH} 6$ the dose of enzyme must be increased and sufficient $\mathrm{Ca}^{++}$must be added to help stabilize the enzyme. From a scientific standpoint it seems that the simple solution to liquefaction at lower $\mathrm{pH}$ would be to increase the dose of the enzyme in the presence of high levels of $\mathrm{Ca}^{++}$. While this should be successful, practical measures make this unworkable. First, increasing the dose of the enzyme has a cost factor associated with it, such that adding enough enzyme to the process becomes quickly uneconomical at lower $\mathrm{pH}$. Second, because of the final product quality specifications, any $\mathrm{Ca}^{++}$added at this stage must be removed through a later ion exchange step. Again, the economic considerations make significantly higher levels of $\mathrm{Ca}^{++}$an unattractive option.

For a protein engineer, we now have a clearly defined set of parameters by which we can identify an improved performance enzyme: an enzyme that is active at lower $\mathrm{pH}$ and does not require additional $\mathrm{Ca}^{++}$to maintain this activity. We began our project with what in retrospect seems a very simple practice- defining the problem in scientific terms. While this may seem a trivial and obvious starting point, it is quite often neither. For example, lack of functional performance of the exist-

\section{C. 酵素液化}

耐熱性 $\alpha$-アミラーゼは澱粉加工に応用された初めての酵素 である。図 1 に示したように伝統的な工程のパラメーターは、 $\mathrm{pH}$ は 6.2 以上で $\mathrm{Ca}$ 存在下である。これらの条件は基本的には その時入手可能なアミラーゼの最低作用範囲に規定されてい る。澱粉の大規模な加水分解に用いられる酵素とその作用部位 を図 2 に示している。業界で使用されている酵素Bacillus licheniformis の $\alpha$-アミラーゼ (BLA; EC3.2.1.1) は、高温での反応 にCa を必要とする。また $\mathrm{pH}$ が低くなるにつれ醳素の反応性は 悪くなり、pH 6 以下で反応させるため、酵素添加量を増やさな ければならないし、また、酵素の安定性を高めるために十分量 の Ca を添加しなければならない。科学的見地から、低い $\mathrm{pH}$ の澱粉の液化には酵素の増量と高レベルの Ca の存在が単純な解 決策である。この方法でうまくいくはずであるが、実際にはこ の方法は実行できない。第一に過剩の酵素添加はコスト要因に なり、工程への大量の酵素添加は急速に $\mathrm{pH}$ を低下させ経済的で なくなる。第二に最終製品の品質規格上、この段階で添加した $\mathrm{Ca}$ は後にイオン交換樹脂で除去する必要がある。即ち経済的観 点からは高濃度の Ca は魅力的でないオプションである。タンパ ク質科学者は今、低い $\mathrm{pH}$ で活性があり、その活性を維持するた めに $\mathrm{Ca}$ の添加を必要としない改良した性能の醅素を確認するた めの明確なパラメーター一式を手に入れている。思い起こせば 我々は科学的言葉で問題を定義するという、非常に単純な慣行 でもってこのプロジェクトに着手した。これは些細で且つ明暸 な出発点のように思われるが、しばしばそうではないことがあ る。例えば既存 $\alpha$-アミラーゼの低い $\mathrm{pH}$ での機能性の欠如は、 酵素の触媒能力の低下、澱粉乳液の成分による酵素の失活、あ 


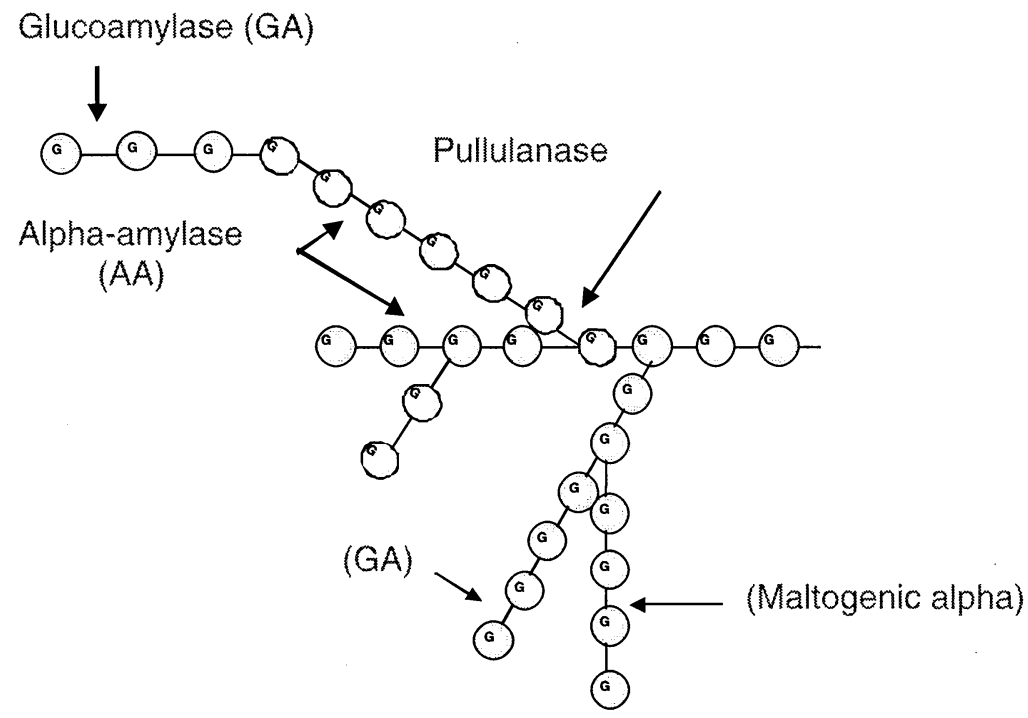

Fig. 2. General structure of a branched amylose molecule and sites of actions of enzymes involved in starch processing.

ing alpha amylases at low $\mathrm{pH}$ could be due to low catalytic efficiency of the enzymes, inactivation of the enzymes by components in the starch slurry or could even be due to structural modifications of the substrate (starch) itself which renders it less accessible to enzymatic hydrolysis. By using a combination of pilot scale applications testing and modeling the existing commercial process at bench scale level we were able to determine that the key issue with the enzyme was not catalytic inefficiency at low $\mathrm{pH}$, but rather that at $\mathrm{pH}<6.2$, the enzyme was rapidly inactivated. In addition we were able to show that the effect of added $\mathrm{Ca}^{++}$was to also give additional thermal protection to the enzyme. Now we could focus our efforts on solving the specific problem of engineering BLA to have improved thermostability at low pH. Previously, the genes for several Bacillus amylases of varying degrees of thermostability had been cloned and sequenced $(3,4,5)$. Gray et al $(6)$ showed that hybrid amylases made by fusion of the structural genes of Bacillus sterarothermophilus and BLA could have varying degrees of stability. Suzuki et al. (7) identified regions of the BLA gene which were associated with increased thermostability and showed that amino acid substitutions in the same regions of the homologous, but less stable, B. amyloliquefaciens amylase could significantly improve its stability at higher temperatures as well. Hyperthermal stable variants of BLA were subsequently constructed and modeled (8). However, none of these studies demonstrated improved enzyme performance under the specific conditions demanded by commercial applications. Our approach combined regio-specific mutagenesis, structural based site recruitment, applications based predictive assays and expression screening to develop a library of BLA variants for further testing. Figure 3 shows the thermostability curves for several of
るいは酵素分解に困難さを与えるような基質 (澱粉) 自身の構造 変化の原因となる。パイロット規模での応用試験とベンチ規模 での既存生産工程のモデル化の両方を使って、我々は問題の鍵 は低 $\mathrm{pH}$ での酵素の触媒能力の非能率化でなく、 $\mathrm{pH} 6.2$ 以下で 酵素が急速に失活することにあるということが分かった。さら に $\mathrm{Ca}$ の添加が酵素の熱安定性を保護するということも示すこ とが出来た。ここで我々は低い $\mathrm{pH}$ での熱安定性を改良するた めにBLA を設計するという具体的問題点の解決に集中すること ができた。これより前に数種の熱安定性の異なる Bacillus アミ ラーゼの遺伝子がクローン化され、その配列が決定されていた (3、4、5)。Gray ら (6) は B. stearothermophillus と BLA の構造遺伝 子の融合により得られたハイブリッドアミラーゼが種々の安定 性を持つことを示した。鈴木ら (7) は熱安定性を高めるのに関 与する BLA 遺伝子領域を同定し、その同類であるが若干安定性 の低いB. amyloliquefaciens のアミラーゼと同じ領域のアミノ酸 の置換により高温での安定性を著しく改良できることを示し た。その後 BLA の超高温で安定な変異体が構築され、手本とさ れた(8)。しかし、商業的応用に必要とされる特殊な条件下にお いては、これらの研究では改良された酵素の性能を実証できる ものではなかった。われわれのアプローチは部位特異的変異、 構造的部位補充、応用面での予測分析および更なるテストのた めの BLA 変異体のライブラリーを作り上げるための発現スク リーニングを結合したものであった。図 3 に $\mathrm{pH} 4.8$ 、高温で且 つ Ca を添加することなしに試験を行った時の数種の変異体の 


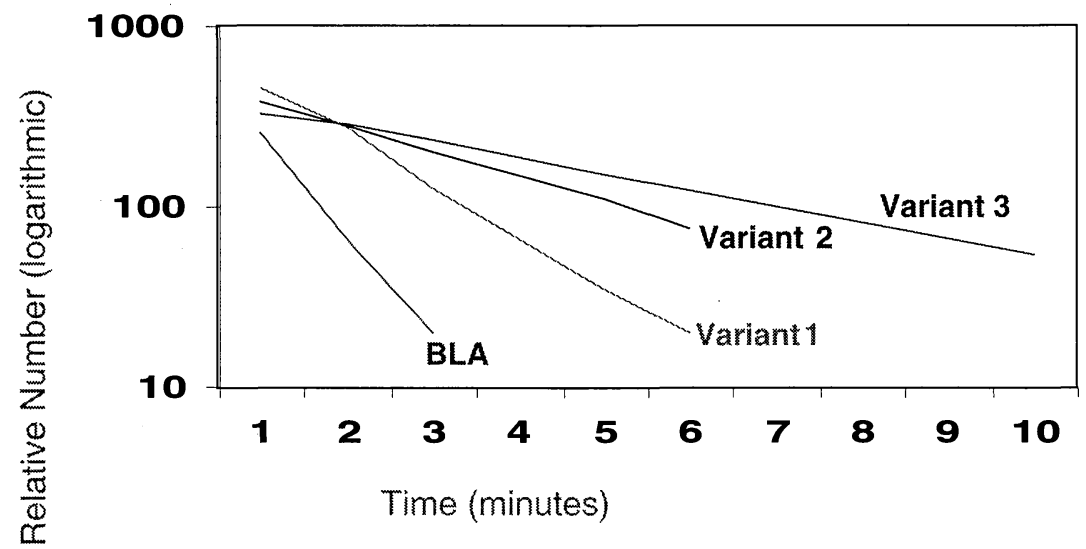

Fig. 3. Inactivation kinetics of native Bacillus licheniformis alpha amylase (BLA) and protein engineered variants. Stability was tested at $\mathrm{pH} 4.8,85^{\circ} \mathrm{C}$ in acetate buffer. Samples were removed at the times indicated and tested for residual amylase activity.

our variants when tested at $\mathrm{pH} 4.8$ at high temperature in the absence of added $\mathrm{Ca}^{++}$. A commercially successful amylase must not only have the proper performance characteristics, it must also be able to be manufactured by large-scale fermentation (> 50,000 L). Variants of an enzyme that can only be expressed at microgram per $\mathrm{ml}$ levels may be of interest from an academic standpoint, but are rarely good candidates for commercialization. Since it is still not possible to predict how specific amino acid changes in an enzyme might affect productivity, it is essential to employ an early screen that evaluates expression levels in a commercially relevant host system. Potential candidates from the above functional screens were subsequently introduced into both Bacillus subtilis and Bacillus licheniformis and tested for expression in $14 \mathrm{~L}$ fermentation systems.

Our approach to engineering BLA resulted in the commercialization of two products. The first was Spezyme DeltaAA. This enzyme allowed the starch processor to drop the $\mathrm{pH}$ operating conditions for liquefaction to at least $\mathrm{pH} 5.8$, and, depending upon the specific operating conditions of a plant, to as low as $\mathrm{pH}$ 5.4. While this may not seem to be a huge drop, one must recall that these operations occur at extremely large scale and minor decreases in the amount of material required for $\mathrm{pH}$ adjustment can have huge impact in cost reductions and materials handling. In fact, however, there are product quality benefits in going to below $\mathrm{pH}$ 6.2. At high $\mathrm{pH}$ and high temperature, the reducing ends of a portion of the starch molecules are chemically isomerized to fructose (Figure 4). Glucoamylase will not cleave the final glycosidic linkage and the resulting dimer of glucose-fructose (maltulose) cannot be processed to glucose, causing a yield loss of up to $2 \%$ (Figure 5). It is this product yield improvement, as much as operating ease, which makes low $\mathrm{pH}$ liquefaction attractive.

As our amylase project continued we found additional
熱安定性を示した。商業的に成功といえるアミラーゼは適当な 性能を持つだけでなく、大規模培養 $(50,000 \mathrm{~L}$ 以上) で製造可能 でなければならない。一酵素の変異体が $\mu \mathrm{g} / \mathrm{ml}$ レベルで発現で きるだけでは学問的には興味を持たれるかも知れないが、商業 的には良い候補になることはほとんどない。酵素の特定のアミ ノ酸の変化が生産性に如何に影響をあたえるか、予測すること は今なお困難ではあるが、商業的に適切な宿主のシステムでの 発現レベルを評価するスクリーニングを早く採用することが必 須である。引き続き上記の機能的スクリーニングから有望な候 補が、B. subtilis と B. licheniformis 両方に導入され、14 L の培養 槽で発現の試験が実施された。

BLA を形質転換する我々の試みから二種類の製品が商品化 された。最初のものは Spezyme Delta AA である。この酵素は澱 粉加工業者が液化の操作条件を少なくとも $\mathrm{pH} 5.8$ まで下げるこ とを許容し、またプラントの特殊な操業条件によっては pH5.4 まで下げることができた。このことは大きな低下であるとは思 えないが、これらの操業が大きな規模で実施され、 $\mathrm{pH}$ 調整に必 要な物質の量が若干減少したことによりコスト削減や、原料の 取り扱いに大きなインパクトをもたらした事を考えてみてほし い。しかしながら、事実、 $\mathrm{pH} 6.2$ 以下で液化することは製品の 品質に利点がある。高 $\mathrm{pH}$ 、高温で澱粉分子の還元性末端は化学 的にフラクトースに異性化される (図 4)。グルコアミラーゼは 最後のグルコシド結合を分解できず、そのためグルコース-フラ クトースの二量体 (マルチュロース) がグルコースにまで分解さ れないので $2 \%$ 程度の収量ロスになる(図 5)。作業の容易さと 同じように製品収量の改良が低 $\mathrm{pH}$ での液化を魅力的にさせて いる。

我々のアミラーゼプロジェクトが続くにつれて、さらによ 

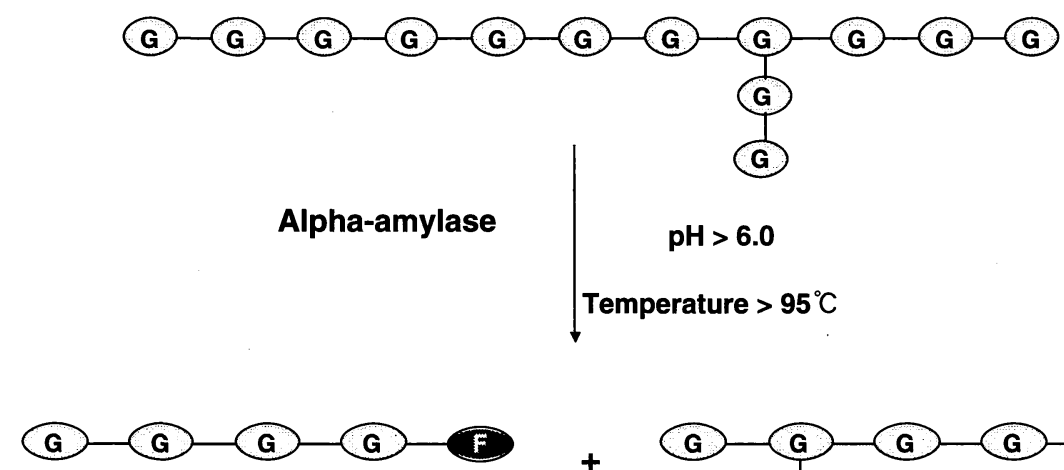

(G: glucose; F: fructose)

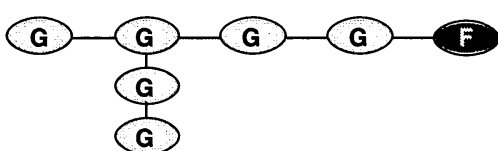

glucoamylase

$+$

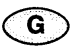

glucose

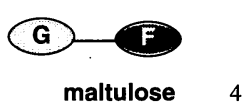

Fig. 4. Formation of maltulose by glucose isomerization to fructose at the reducing end of starch molecules during high temperature liquefaction of starch at $\mathbf{p H}>6.0$.

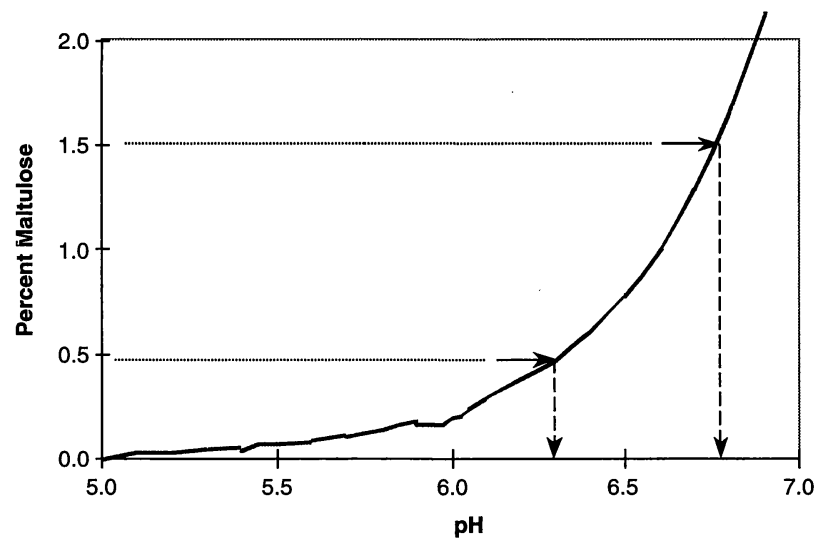

Fig. 5. Formation of maltulose during starch processing relative to processing pH. Starch was liquefied for 5 minutes at $105^{\circ} \mathrm{C}$ followed by a 90 minute hold at $95^{\circ} \mathrm{C}$. Maltulose was measured by HPLC analysis and calculated as the percent of total carbohydrate present after saccharification with glucoamylase.

variants that could provide significant performance advantages at even lower $\mathrm{pH}$. Spezyme Fred was our second-generation engineered amylase and could allow one to liquefy as low as 5.0 without adding any additional $\mathrm{Ca}^{++}$(Figures $6 \mathrm{a}, 6 \mathrm{~b}$ ). Since this could provide all the benefits of Spezyme Delta at even lower $\mathrm{pH}$ operations it quickly became the preferred enzyme for HFCS processing. Table I shows some of the performance characteristics for these three commercial alpha amylases. Today, Genencor continues to look for improved amylases with lower $\mathrm{pH}$ profiles. As with the start of the program, these candidates must offer value to the customer and must have a high
り低い $\mathrm{pH}$ でも著しい効果能力を与える追加の変異体が見出さ れた。Spezyme Fred は我々の 2 世代目の形質転換アミラーゼで あり、Ca の添加なしで、pH 5.0 でも液化することを可能にし た。(図 6a、6b)これがさらに低いpH の操業でも Spezyme Delta のすべての利点を提供できるがゆえに、Spezyme Fred は異性化 糖製造のための選ばれた酵素になった。表 I にこれら三種類の 市販 $\alpha$-アミラーゼの性能の特質のいくつかを示した。現在 Genencor はさらに低 $\mathrm{pH}$ で作用する改良されたアミラーゼの探 查を続けている。このプログラムの最初に述べたように、これ らの候補は顧客に価値を提供するもので、コスト面でも価値の 


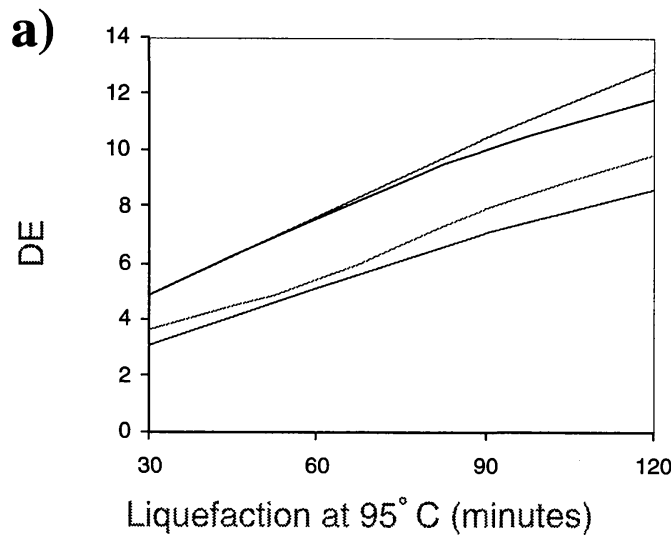

Liquefaction Conditions: $35 \%$ dsb, Primary - $107^{\circ} \mathrm{C}$, 5 minutes, $20 \mathrm{ppm} \mathrm{Ca}^{++}, 50 \mathrm{ppm} \mathrm{SO}_{3}{ }^{2-}$

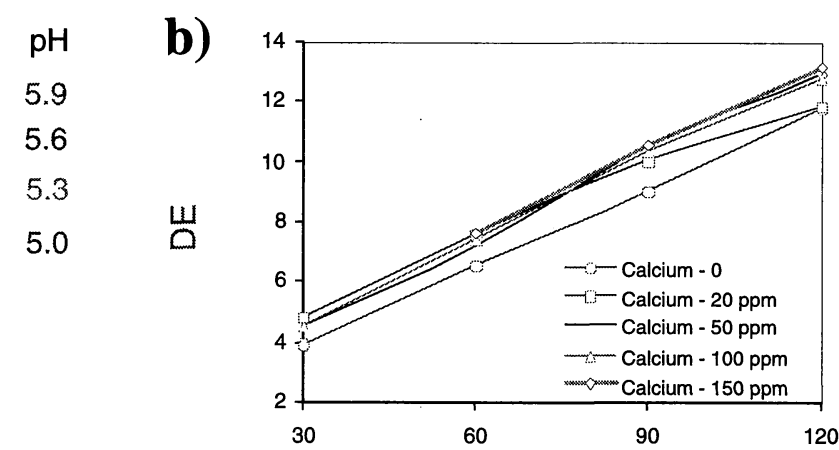

Liquefaction at $95^{\circ} \mathrm{C}$, (minutes)

Liquefaction Conditions: $35 \%$ dsb, $\mathrm{pH} 5.6$, Primary $-107^{\circ} \mathrm{C}, 5$ minutes, $50 \mathrm{ppm} \mathrm{SO}_{3}^{2-}$

Fig. 6. a) Effect of pH on the extent of hydrolyisis of starch during the secondary hold. Commercial starch slurry was adjusted to the $\mathrm{pH}$ indicated and $\mathrm{Ca}^{++}$was added to $20 \mathrm{ppm}$. Spezyme ${ }^{\mathrm{TM}}$ Fred was added at 10 Liquefaction Units/g starch (dry solids basis). The enzyme containing slurry was passed through a jet cooker at $105^{\circ} \mathrm{C}$ for 5 minutes. The secondary hold reactor was at $95^{\circ} \mathrm{C}$ for 90 minutes. Starch hydrolysis was measured by the increase in reducing sugar. b) Effect of calcium on starch hydrolysis using Spezyme ${ }^{\mathrm{TM}}$ Fred. Starch was dialyzed to remove residual calcium. Calcium was then added back to the slurry to the indicated levels and the starch was liquefied at pH 5.6 as described above.

Table I. Comparison of operating parameters for native and engineered Bacillus licheniformis alpha amylases.

\begin{tabular}{|l|l|l|}
\hline $\begin{array}{l}\text { Spezyme } \\
\mathrm{pH}>6.2\end{array}$ & $\begin{array}{l}\text { Spezyme } \\
\mathrm{pH} ~ 5.6-5.8\end{array}$ & $\begin{array}{l}\text { Spezyme }^{\mathrm{TM}} \text { Fred } \\
\mathrm{pH} 5.2-5.6\end{array}$ \\
\hline $50-100 \mathrm{ppm} \mathrm{Ca}^{++}$ & $20 \mathrm{ppm} \mathrm{Ca}^{++}$ & No added $\mathrm{Ca}$ required \\
\hline $\begin{array}{l}\text { Maximum jet } \\
\text { temperature }=105^{\circ} \mathrm{C}\end{array}$ & $\begin{array}{l}\text { Maximum jet } \\
\text { temperature }=107^{\circ} \mathrm{C}\end{array}$ & $\begin{array}{l}\text { Maximum jet } \\
\text { temperature }=110^{\circ} \mathrm{C}\end{array}$ \\
\hline
\end{tabular}

Spezyme $^{\mathrm{TM}}$ AA is the native BLA; Spezyme ${ }^{\mathrm{TM}}$ Delta and Spezyme ${ }^{\mathrm{TM}}$ Fred are engineered version of BLA. Spezyme ${ }^{\mathrm{TM}}$ is a registered trademark of Genencor International.

probability of being translated into cost effective products. To do so, they must address a defined customer need, they must fit into existing starch processing plants with minimal capital or process changes required and they must have a clear route to low cost large scale manufacturing.

\section{Enzymatic Saccharification}

Following liquefaction of the starch to oligosaccharides of a desired size, the starch is converted to glucose by the action of glucoamylase (GA; EC 3.2.1.3). Commercial saccharifications are usually performed as large plug flow reactors. Liquefied starch, with a Dextrose Equivalent (DE) between 8-10 (average oligosaccharide size is 10 glucose residues) is adjusted to $\mathrm{pH} 4.2$, cooled to $60^{\circ} \mathrm{C}$ and enzyme is added. During time of
ある商品と云われる高い可能性を持ったものでなければならな い。そうすることが、明確な顧客のニーズに応え、必要とされ る最小の資本投資又は工程変更で既存の澱粉加工プラントに適 合し、低コストの大規模製造への明確な道筋を持つことにな る。

\section{D. 醰素糖化}

適切なサイズのオリゴ糖への澱粉の液化に引き続いて、澱 粉はグルコアミラーゼ (GA; EC3.2.1.3) の作用でグルコースに転 換される。工業的糖化は通常ラージプラグ フローリアクター で行われる。DE8-10 (平均オリゴ糖サイズ 10 グルコース残基) の液化澱粉は、 $\mathrm{pH} 4.2$ に調整、 $60^{\circ} \mathrm{C}$ に冷却され、醭素が添加さ れる。異性化糖の高需要期 (例えば夏期) には、製造能力を增大 
high fructose demand (summer months for example) shorter saccharifications can be run to increase plant capacity. During lower demand times, saccharifications can be extended by using less GA and holding the reactions for longer times. Reactor times can vary from as short as $24 \mathrm{hrs}$ to as long as $>90 \mathrm{hrs}$ depending upon the individual plant design and plant throughput needs. GA acts in a strictly exo- fashion, removing single units of glucose from the non-reducing end of the oligosaccharide chains. Conceptually one would think that this would result in complete conversion of the starch to glucose. In practical terms however the GA is limited in two respects. First, the preferred substrate for GA is $\alpha-1,4$-glycosidic linkages. Starch contains $\alpha-1,6$-branch points and GA is less effective in hydrolyzing these branches. Second, at glucose concentrations $>90 \%$, GA will demonstrate reverse reaction activity, forming maltose, isomaltose and other di- and tri-sachharides, know collectively as "reversion products". Combined, these two characteristics of low efficacy against $\alpha$-1,6-linkages and formation of reversion products leave room for improvement.

Nikolov et al. (9) demonstrated reverse reaction in high glucose syrups using purified GA and showed that these reversion reactions can decrease the final glucose yield. Figure $7 \mathrm{dem}-$ onstrates the loss of glucose yield during saccharifications at increasing dosages of GA. With reversion product formation a reality in the manufacturing plant, operations are limited by the amount of GA that can be added to a reactor without losing glucose yield. Balancing the dosage of GA to maximize plant productivity while minimizing yield loss can often be a challenge for the efficient plant operations. Sierks and Svensson (10) addressed this problem by using protein engineering to increase the selectivity of GA for $\alpha-1,4$ linkages by destabilizing the iso-
するために短時間で糖化が行われる。低需要期には GA の使用 量を少なくし、糖化時間は引き延ばされ、反応を長時間行う。 各々のプラント デザインおよびプラントの生産量の必要性に 応じて、反応時間は最短 24 時間から最長 90 時間以上に変化が 可能である。GA は厳密にエキソ型に作用し、オリゴ糖の非還元 末端からグルコースのみを遊離させる。概念的には、これは澱 粉をグルコースに完全に転換するものと考えられる。しかし実 際上 GA は二つの点で制約をうけている。第一に GA に適した 基質は $\alpha-1-4$ グルコシド結合である。澱粉は $\alpha-1-6$ 結合の分枝 点を含んでおり、GA はこれらの分枝を加水分解する能力は弱 い。第二に、グルコース濃度 $90 \%$ 以上では $\mathrm{GA}$ は逆反応を触 媒し、縮合生成物として知られているマルトース、イソマル トース拉よびその他二糖類、三糖類を生成する。 $\alpha-1-6$ 結合に対 する低い反応性と逆反応生産物の生成というこれら二つの特質 に改良の余地を残している。

Nikolov らは (9)、精製された GA を用いて高濃度のグルコー ス溶液での逆反応を立証し、これらの逆反応が最終のグルコー ス収率を減少させることを示した。図 7 は糖化の過程で GA 添 加量の増加がグルコース収率を低下させることを示している。 逆反応生産物の生成によって生産工場および操業の現実は、グ ルコース収率のロスなしにリアクターに添加できる GA の量に よって制限される。収率の損失を最小にして、工場の生産性を 最大限にするために $\mathrm{GA}$ の添加量を釣り合わせることは、しば しば効果的なプラント操業にとっての挑戦となる。Sierks と Svensson (10) は、タンパク質工学を使用してイソマルトースの 遷移状態複合体の不安定化によって、 $\alpha-1,4$ 結合への GA の選

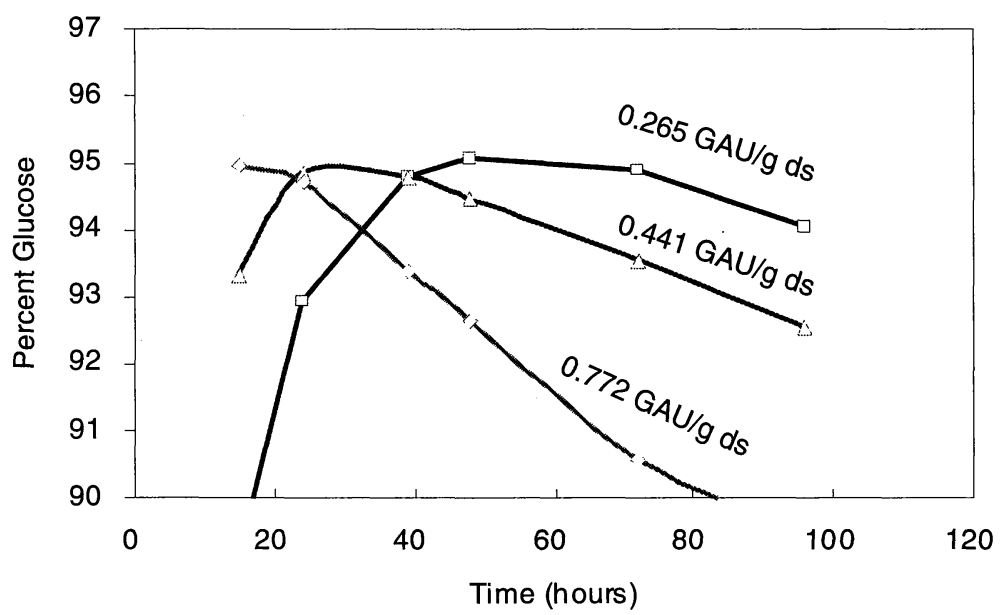

Fig. 7. Effect of glucoamylase (GA) levels on loss of glucose due to reversion during saccharification. A liquefied starch slurry ( $32 \% \mathrm{dsb})$ was prepared using standard methods. The slurry was adjusted to $\mathrm{pH} 4.2$ and GA was added at the indicated activity levels. Saccharification was carried out at $60^{\circ} \mathrm{C}$ and glucose was measured by HPLC at the indicated times. 
maltose transition state complex. By making amino acid changes in the active site region of GA they were able to demonstrate up to a 3.5 fold increase in the selectivity of the variant enzymes for $\alpha-1,4-$ versus $\alpha-1,6-$ glycosidic linkages. In an elegant series of additional studies Reilly and co-workers (11-14) were able to show that there was an inverse relationship between peak glucose attained and the ratio of initial rates of isomaltose formation from glucose condensation to the rate of maltodextrin hydrolysis to glucose. By comparing these ratios in a series of GA variants, one could increase the peak glucose yield by up to $2 \%$ or decrease it by up to $4 \%$ depending upon the variants chosen (15). Given such successes in GA engineering one may ask why engineered GAs have not taken over the market as have engineered alpha amylases. The answer can be found in an additional enzyme, pullulanase, which has taken on greater commercial significance. Pullulanase catalyzes the hydrolysis of $\alpha$ 1,6-linked branch points of starch. Previous to the wide spread commercial use of pullulanase, higher doses of GA were required to rapidly hydrolyze the branch linkages. With pullulanase present, the $\alpha-1,6$-linkages are efficiently hydrolyzed and the saccharification requires significantly lower GA levels to reach peak glucose in the same time frame as previously. These GA/ pullulanase blends can replace up to $80 \%$ of the amount of GA required for a saccharification to be successful. With such lowered amounts of GA, reversion typically becomes less of an issue during normal saccharifications. Table II shows a comparison of peak glucose yields for commercially available products containing GA alone and the newer blends containing pullulanase. Since the introduction of blended saccharification products, the need for an engineered GA that has decreased ability to yield reversion products has become significantly less. Yet glucoamylases remain an interesting and active area of research. Work continues in understanding the catalytic mechanism of Aspergillus GA (16) as well as searching for novel GAs with
択性を増大させることで、この問題に取り組んだ。GAの活性中 心領域のアミノ酸を変えることで、彼らは形質転換酵素の $\alpha-1,4$ グルコシド結合に対する $\alpha-1,6$ グルコシド結合の選択性を 3.5 倍にまで増加させることを可能にした。更なるすばらしい一連 の研究で、Reilly とその共同研究者たちはマルトデキストリンの 加水分解によるグルコース生成速度に対して、得られたグル コース量とグルコースからの逆反応によるイソマルトース生成 の初期反応速度との間には逆の関係があることを立証した。一 連の $\mathrm{GA}$ 形質転換酵素を用いて、これらの割合を比較すること で、選択された変異体によって、最大グルコース収率を $2 \%$ ま で増加、または $4 \%$ まで減少させることができた(15)。 GA 形 質転換酵素で得られたこのような成功で、何故形質転換醭素の GA は、形質転換酵素の $\alpha$-アミラーゼのように市場を席捲しな いのか、という疑問がでてくる。その答えはより大きな商業的 重要性の意味を持つもう一つの酵素であるプルラナーゼにあ る。プルラナーゼは澱粉の $\alpha-1-6$ 結合分枝点の加水分解を触媒 する。プルラナーゼが広範囲に商業的に使用されるまでは、GA のより多量の添加が分枝結合を速やかに加水分解するために必 要とされた。プルラナーゼの出現で、 $\alpha-1-6$ 結合は効果的に加水 分解され、糖化は非常に少ない $\mathrm{GA}$ の量で、以前と同様の時間 で最大のグルコース生産量に達するようになった。これら GA とプルラナーゼを混合して用いることにより、糖化をうまく行 うために必要とされる GA の量を $80 \%$ まで置き換えることが 可能である。このような低い GA の添加量では、通常の糖化に おいて逆反応はそれほど問題にはならない。表 II は商業的に入 手できる GA のみとプルラナーゼを含む混合品とのグルコース の最大収率の比較を示している。ブレンド糖化酵素の導入以 来、逆反応生産物の収率を減少させる能力を有した形質転換 $\mathrm{GA}$ の必要性は非常に少なくなった。グルコアミラーゼはいまだに 興味深い研究活動の分野である。研究は Aspergillus GA の触媒 メカニズムを理解するとともに、興味深いそして多分有用な性

Table II. Performance characteristics of GA and GA/Pullulanase blends during normal saccharification reactions. (32\% liquefied starch (dry solids basis), $\mathrm{pH} 4.2,60^{\circ} \mathrm{C}, 24-72 \mathrm{hrs}$ reaction time)

\begin{tabular}{|l|l|l|l|}
\hline Product & Optidex $^{\mathrm{TM}}$ & Optimax $^{\mathrm{TM}} 7525 \mathrm{HP}$ & Optimax $^{\mathrm{TM}} \mathrm{HiDex}$ \\
\hline Peak Dextrose & $95.5 \%$ & $96.2 \%$ & $>97 \%$ \\
\hline $\begin{array}{l}\text { Percent reversion product } \\
\text { formation* }\end{array}$ & $4 \%$ & $2.5 \%$ & $2.0 \%$ \\
\hline $\begin{array}{l}\text { Maximum solids to } \\
\text { reach 95.5\% Dextrose }\end{array}$ & $30 \% \mathrm{ds}$ & $36 \% \mathrm{ds}$ & $40 \% \mathrm{ds}$ \\
\hline
\end{tabular}

* Maximum reversion product formation (measured by HPLC) at peak dextrose formation at $32 \%$ dry solids, $\mathrm{pH} 4.2$ and $60 \mathrm{C}$. Optide ${ }^{\mathrm{TM}}$ contains $100 \%$ GA; Optimax ${ }^{\mathrm{TM}} 7525$ HP contains $75 \%$ GA/25\% pullulanase; Optimax ${ }^{\mathrm{TM}}$ HiDex contains $20 \%$ GA/80\% pullulanase. Opitdex and Optimax are registered trademarks of Genencor International. 
interesting and perhaps useful properties $(17,18)$. A recent review of GA structure/function relationships has been published (19).

\section{E. Regulatory Considerations}

It is not sufficient to discuss the commercial implications of a technology without including discussions of other issues that have impact on the ability to bring new products to the market place. For enzyme products in the starch processing industry, the regulatory issues are not insurmountable, but neither are they negligible. Products to be introduced to the market need to be validated for safety as well as efficacy. Pariza and Johnson (20) have recently reviewed the safety considerations for microbial enzymes in the food sector, including those used in starch processing. Generally safety can be supported by toxicology studies, which are fairly straightforward and well defined. These studies can add additional cost and time in bringing a product to the market, and these costs must be considered as part of an overall evaluation of the project. A usual outcome of such studies is a determination that the product is "Generally Recognized As Safe" (GRAS). An additional challenge in the regulatory arena is that there is not global unity in the safety assessment and clearance processes for products derived from genetically modified microorganisms (GMM) and the regulatory needs for various countries may differ and are in a state of flux. This means that it may be difficult to accurately predict how quickly one can obtain clearance to market products, especially when regulatory agencies are addressing GMM derived enzymes or protein engineered enzyme products for the first time.

\section{F. Summary}

Protein engineering has become a powerful and relatively common tool to improve the performance of enzyme products for a variety of industries, including the starch processing industry. Engineered alpha amylases have become the predominant enzymes for the US based starch processors. Their acceptance has been based on a number of factors, including the ability to deliver a customer desired performance benefit, achievement of large scale production economics acceptable to the customer and regulatory clearance. In the absence of any one of these factors, commercialization becomes difficult. An engineered glucoamylase, the second major amylolytic enzyme for starch processing, has yet to become widespread in the industry. This is not due to a lack of success in engineering improved performance properties into the molecule, as Reilly and others have clearly demonstrated improved characteristics of the enzyme. Rather, one of the key process conditions driving the need for an improved GA, namely the formation of reversion products under the conditions of high glucose levels, high GA levels and long retention times during saccharification have been
質を持つ新しい $\mathrm{GA}$ を探索 $(17,18)$ するという点で、引き続き 行われている(16)。GAの構造/機能の関係に関する最近の解説が 発表されている(19)。

\section{E. 規制に関する考察}

新製品を市場に導入できるかどうかに影響を与えるその他 の問題の議論をしないで、技術の商業的意味を議論するのは、 十分ではない。澱粉加工業界における酵素製品については、規 制の問題は克服できない問題ではないが、また無視できるもの でもない。市場に導入されようとしている製品は効果と同様に 安全性についても確証される必要がある。Pariza と Johnson は、 最近フード セクター (20) の中で、澱粉加工に使われている酵 素を含めた微生物酵素の安全性について考察している。一般的 に安全性は毒性試験で立証されており、それらは大変直接的で あり、よく明示されている。これらの試験は市場に製品を出す ために追加の費用と時間を要し、これらの費用はプロジェクト の全体評価の一部とみなされる。このような試験の通常の結果 は、その製品が “Generally Recognized As Safe” (GRAS) である ことを決定することにある。規制の分野での更なる挑戦は、 genetically modified microorganisms (GMM) から得られた安全性 評価と承認の過程で世界的な統一がないことであり、それぞれ の国での申請に必要なものは、国ごとに異なり、変化する。こ れは、いかに速く製品を市場にだすために承認を取得できる か、特に GMM から得られた酵素又はタンパク質工学で得られ た酵素製品を関係当局が初めて審査する場合には、正確に予測 することが困難であることを意味する。

\section{F. 要 約}

タンパク質工学は、澱粉加工工業を含めた様々な産業に とって酵素製品の特性改良の力強い、そして比較的一般的な道 具となっている。形質変換体の $\alpha$-アミラーゼは米国の澱粉加工 業者にとって有力な酵素となった。彼らのこの酵素の受け入れ には、顧客の希望する効果利益の提供、顧客に受け入れられる 大規模生産での経済性の達成および規制にたいする許可の取得 を含めた、様々な要素に基づいている。これらの要素の一つで も欠けたときには、商業化は難しくなる。澱粉加工用の第二の 主要な澱粉分解酵素の形質転換グルコアミラーゼはいまだ業界 に普及していない。これは、Reillyらがこの酵素の改良された特 性を明らかに示したように、酵素分子に改良された性能特質を 遺伝子工学的に導入することに成功しなかったためではない。 むしろ改良された GA を必要とする重要な工程の条件の一つ、 即ち糖化の際、高濃度のグルコース、高い GA 量および長い反 応時間の条件下での逆反応生産物の生成は、プルラナーゼと $\mathrm{GA}$ 
changed by the introduction of new blended pullulanase/GA products which solved the problem in a different manner.

The starting assumption of this paper was that the successful application of protein engineering to commercially relevant projects in the starch processing industry was based on understanding three key criteria beyond the technology. A clear definition of the problem to be solved must be understood in the framework of the production processes in standard use throughout the industry. With amylase, for example, there was a clear desire to decrease the operating $\mathrm{pH}$ range of the liquefaction process without increasing the ion exchange load in later processing steps. A successful product could therefore be defined as one that allowed liquefaction at $\mathrm{pH}$ 5.4-5.6 without additional $\mathrm{Ca}^{++}$. Second, one must be able to quantitate the overall value of the process to the processor. In the case of lower $\mathrm{pH}$ liquefaction, additional value was achieved by lowering the amount of the byproduct maltulose. While operational reasons can drive new product introduction, improvements in both product quality and yield can help prove the value of the new product and aid in customer acceptance. Third, no product can be successful if it cannot be delivered to the customer due to regulatory or economic production factors. Scientific success alone will not necessarily translate in to product success. Only in those situations where one can clearly meet all of the above criteria will a protein-engineering project be come successful at the commercial scale.
を混合した新しい製品を使用するという異なった方法でこの問 題を解決したためである。

本稿の最初の想定は、澱粉加工工業での商業的に適切なプ ロジェクトにタンパク質工学を成功裏に応用するための、技術 を超えた三つの重要な基準を理解することにあった。解決され なければならない問題の明らかな定義は、その業界での標準的 な使用の製造工程の枠組みの中で理解されなければならない。 例えば、 $\alpha$-アミラーゼでは、その後の工程でのイオン交換の負 荷の増加なしに、液化工程の最適 $\mathrm{pH}$ の範囲を低くするという 明らかな要請があった。したがって、成功した製品は、 $\mathrm{Ca}^{++}$の 更なる添加なしに、 $\mathrm{pH}$ 5.4 5.6で液化できるものとして定義で きた。第二に、加工者に工程での全体的な価値を定量すること ができなければならない。低い $\mathrm{pH}$ で液化する場合、さらなる 利点は副産物のマルチュロース量を低減することができたこと である。操作上の理由が新製品の導入に駆り立てる一方、製品 の品質と生産性の両者の改良が、新製品の価值を証明し、顧客 による受け入れの支援をした。第三に、規制又は経済的生産と いった要素のために製品が顧客に届けられなければ、その製品 は成功したとはいえない。科学的成果だけでは製品の成功とは 必ずしもいえない。上記基準に明白に合致する条件においての み、タンパク質工学は商業的に成功したことになる。

KTBコンサルティング

田治 襄 訳

\section{References}

1. Crabb, W. D., and Mitchinson, C. (1997) Trends Biotechnol. 15, 349-352

2. Crabb, W. D., and Shetty, J. K. (1999) Current Opin. Microbiol. 2, 252-256

3. Nakjima, R., Imanaka, T., and Alba, S. (1985) J. Bacteriol. 163, 401-406

4. Takkinen, K., Petersson, R.E., Kalkkinen, N., Palva, I., Soderlund, H., and Kaariainen, L. (1983) J. Biol. Chem. 258, 1007-1013

5. Young, M., Gallizzi, A., and Henner, D. (1983) Nucleic Acids Res. 11, 237-249

6. Gray, G., Mainzer, S.E., Rey, M.W., Lamsa, M.H., Kindle, K.L., Carmona, C., and Requadt, C. (1986) J. Bacteriol. 166, 635-643

7. Suzuki, Y., Ito, N., Yuuki, T., Yamagata, H., and Udaka, S. (1989) J. Biol. Chem. 264, 18933-18938

8. Declerck, N., Jiyet, D., Trosset, J.Y. Garnier, J., and Guillardin, C. (1995) Protein Eng. 8, 1029-1037

9. Nikolov, Z.L., Meagher, M.M., and Reilly, P.J. (1989) Biotechnol. Bioeng. 34, 694-704

10. Sierks, M., and Svennson, B. (1994) Protein Eng. (1994) 7, 1479-1484

11. Coutinho, P., Dowd, M.K., and Reilly, P. J. (1997) Proteins 28, 162-163

12. Coutinho, P., and Reilly, P.J. (1997) Proteins 29, 334-347

13. Fang, T.Y., Coutinho, P., Reilly, P.J., and Ford, C. (1998) Protein Eng. 11, 119-126

14. Fang, T.Y., Honzatko, R.B., Reilly, P.J., and Ford, C. (1998) Protein Eng. 11, 127-133

15. Liu, H.S., Coutinho, P., Ford, C., and Reilly, P.J. (1998) Protein Eng. 11, 389-398

16. Giardina, T., Guning, A.P., Juge, N. Faulds, C.B., Furness, C.S., Svensson, B., Morris, V.J. and Williamson, G. (2001) J. Mol. Bio. 313, 11491159

17. Uotsu-Tomita, R., Tonuzuka, T., Sakai, H., and Sakano, Y. (2001) Appl. Micorbiol. Biotechnol. 56, 465-473

18. Bertaldo, C., and Antrnikian, G. (2002) Curr. Opin. Chem. Biol. 6, 151-160

19. Sauer, J., Sigurkjold, B.W., Christensen, U., Frandsen, T.P., Mirgorodskaya, E., Harrison, M., Roepstorff, P., and Svensson, B. (200) Biochem. Biophys. Acta 1543, 275-293

20. Pariza, M.W., and Johnson, E.A. (2001) Regul. Toxicol. Pharmacol. 33, 173-186 


\section{Profile of the Authors}

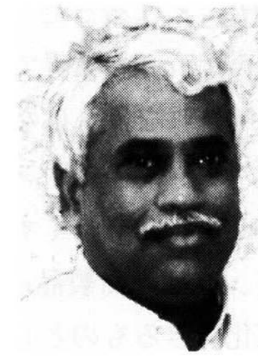

Dr. Jay K. Shetty, Senior Director at Genencor International, Inc., Palo Alto, California, USA, is responsible for Marketing \& Sales of Grain Processing and Specialty Enzymes for the Asia Pacific region. He got his Ph.D. degree in Biochemistry from the University of Mysore, Karnataka State, India. He did his post-doctoral work at Cornell University, New York and joined the Biotechnology Group of Miles Laboratory in Elkhart, Indiana as a Research Scientist in 1981 and then moved to Solvay Enzymes as head of Research \& Development in 1988 before joining Genencor in 1996. Dr. Shetty has worked on various aspects of enzyme biotechnology including fermentation, recovery and applications. He holds more than 35 patents besides research publications in reputed journals and books. Currently he is actively involved in creating new products and processes for the production of ethanol as a renewable energy source from agricultural raw materials.

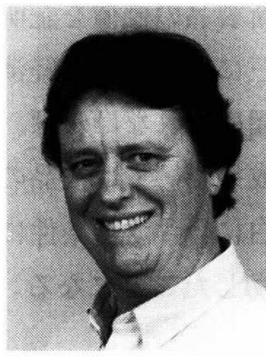

Dr. Crabb received his Ph.D. in microbial genetics from the University of Louisville School of Medicine in Louisville, KY. His research interests are in protein expression and manufacturing using the tools of biotechnology to design novel proteins for commercial applications. Dr. Crabb joined Genencor International in 1982 and has held various levels of scientific positions within the company, most recently as Vice President of Research Operations. Dr. Crabb has been responsible for a number of products within the carbohydrate processing industry and was the project leader for the introduction of the first engineered amylase for starch processing. Dr. Crabb holds a black belt in Shorin Ryu karate and is an avid advanced scuba diver when time and location allows. 